This is the final peer-reviewed accepted manuscript of:

Polonia, A.; Romano, S.; Cagatay, M. N.; Capotondi, L.; GASPAROTTO, GIORGIO; Gasperini, L.; Panieri, G.; Torelli, L.: Are repetitive slumpings during sapropel S1 related to paleo-earthquakes? MARINE GEOLOGY 361. 0025-3227

DOI: 10.1016/j.margeo.2015.01.001

The final published version is available online at:

http://dx.doi.org/10.1016/j.margeo.2015.01.001

Rights / License:

The terms and conditions for the reuse of this version of the manuscript are specified in the publishing policy. For all terms of use and more information see the publisher's website.

This item was downloaded from IRIS Università di Bologna (https://cris.unibo.it/)

When citing, please refer to the published version. 


\title{
Are repetitive slumpings during sapropel S1 related to paleo-earthquakes?
}

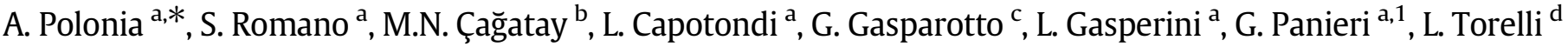 \\ a ISMAR (Institute of Marine Sciences), CNR, Bologna, Italy \\ b Istanbul Technical University, Department of Geological Engineering, Istanbul, Turkey \\ c Dipartimento di Scienze Biologiche, Geologiche e Ambientali, University of Bologna, Italy \\ d Dipartimento di Fisica e Scienze della Terra “Macedonio Melloni”, University of Parma, Italy
}

\begin{abstract}
A B S T R A C T
The recurrence of mass flow units within sapropel S1, an organic carbon rich lower Holocene marker bed in the Eastern Mediterranean Sea, was used to study the interplay between earthquakes and sedimentation along the seismically active Calabrian Arc (Ionian Sea).

Nine turbidite beds interrupt anoxic conditions during the deposition of sapropel $\mathrm{S1}$. Each of these turbidites is associated with sharp grain size and geochemical elemental anomalies (high $\mathrm{Al}$ and $\mathrm{Si}$, low $\mathrm{Ca}$ and coarse grained basal part marked by $\mathrm{Zr}$ peaks), and with displaced foraminiferal species from different bathymetric ranges. We used these proxies to identify turbidite beds also above and below the sapropel, where turbidite signature is less clear due to the absence of major color changes. Turbidite structure and composition, as well as comparison with historical seismoturbidites, suggest a seismic triggering for such mass flow events. The peculiar color, well known composition, geochemistry and age of sapropel S1, make this unit a key bed within which turbidites may be considered a sort of sedimentary "bar code" recording high energy events within the background pelagic sedimentation; deciphering this code will reconstruct paleo seismicity in this well defined stratigraphic interval.

The pelagic units bracketing turbidite beds were radiometrically dated, and the age of the sapropel S1, deduced through age modeling, is between 6.0 and $10.2 \mathrm{kyr}$ cal BP. The emplacement age of each turbidite was estimated considering the average time interval between successive turbidite beds (from pelagic sediment thickness and sedimentation rate). Subsequently these ages were further refined through age modeling. In this way, we compiled a catalogue of mass flow events during sapropel S1 deposition, a time span long enough to include several earthquake cycles and allow reliable seismic and tsunami hazard assessment in this area.
\end{abstract}

Keywords:

Calabrian Arc subduction complex

Ionian Sea

sapropel S1

seismoturbidites

earthquakes

recurrence time

\section{Introduction}

Turbidite paleoseismology is a well established technique to reconstruct seismicity in tectonically active submarine regions (Goldfinger et al., 2012 and references therein) that has been applied in different geodynamic settings (Goldfinger et al., 2003, 2007, 2008; Goldfinger, 2011; Nelson et al., 2009a,b; McHugh et al., 2006; Gracia et al., 2010; Patton et al., 2010; McHugh et al., 2011; Cagatay et al., 2012; Pouderoux et al., 2012; Barnes et al., 2013; Polonia et al., 2013a, 2013b; Strasser et al., 2013; Van Daele et al., 2013).

Turbidites, debris flows and mega turbidite units in the sedimentary succession of the Ionian Sea were used to study relationships between major earthquakes and sedimentation along the Calabrian and Hellenic

\footnotetext{
* Corresponding author. Tel.: + 390516398888.

E-mail address: alina.polonia@ismar.cnr.it (A. Polonia).

1 Present address: CAGE - Centre for Arctic Gas Hydrate, Env. and Climate, UiT The Arctic University of Norway, Tromsø, Norway.
}

subduction systems (Stanley, 1981; Kastens, 1984; Anastasakis and Piper, 1991; Polonia et al., 2013a, 2013b).

The analysis of resedimented units recovered in the abyssal plain, their detailed radiometric dating and age modeling, were used to unravel relationships between sediment instability and seismic shaking along the continental margins of Sicily and Calabria (Polonia et al., 2013a). This study shows that more than $90 \%$ of sediments in the Ionian abyssal plain is related to seismic shaking, tsunamis and submarine mass move ments. Turbidites triggered by large $\left(\mathrm{M}_{\mathrm{w}}>7\right)$ magnitude earthquakes in the Messina Straits region were found in the Ionian Sea abyssal plain.

A good match between earthquakes and turbidites was established for events included in the seismic catalogues that occurred during the last two millennia (CPTI Working Group, 2004). Nothing is known about pre historic earthquakes, hindering a good understanding of the overall seismic behavior of the Calabrian Arc (CA) subduction system. In fact, the lack of thrust type seismicity in the offshore CA, is a debated issue, that could be explained by the inadequate geometry of the seismic network or by the peculiar seismic behavior of this convergent margin. 
Several different scenarios can be envisioned, such as aseismic subduction or locked subduction thrust, implying large events with long repeat time similar to the Tohoku, Sumatra or even Cascadia case histories. To test which one of these hypotheses better represents the $\mathrm{CA}$, it is essen tial to reconstruct seismic activity back in time using a submarine paleoseismological approach as was done, for example, in the Cascadia margin (Goldfinger et al., 2003, 2012).

Neogene and Quaternary sediments of the Mediterranean Sea are characterized by organic carbon rich layers, with Total Organic Carbon (TOC) usually $>2 \%$, named sapropels (Kidd et al., 1978). Formation of these TOC enriched deposits appears to be controlled mainly by astronomical forcing, leading to periods of wetter climate in the Mediterranean region, with increased freshwater input, water column stratification and improved preservation of organic matter under anoxic bottom water conditions (Rossignol Strick et al., 1982; Rossignol Strick, 1985; De Lange et al., 1990; Rohling and Hilgen, 1991; Thompson et al., 1999; Mercone et al., 2001; Rohling et al., 2002).

The most recent sapropel unit (S1) was deposited between 10.4 $5.7 \mathrm{ka}$ cal. BP (Mercone et al., 2000) or $10.86 .1 \mathrm{ka}$ cal. BP (De Lange et al., 2008). S1 may be considered a key bed in the Ionian Sea because: 1 ) it is synchronous in the whole basin (De Lange et al., 2008); 2) it has a high organic content (Thomson et al., 1999); and 3) it stands out in the chemo stratigraphic log for its geochemical signatures (sharp increase in $\mathrm{Ba}$ at the base and $\mathrm{Mn}$ peak at its top). For these reasons, its top and bottom boundaries can be accurately detected and constitute stratigraphic markers. Any mass flow process occurring during sapropel deposition is marked by strong contrasts in sediment composition and geochemistry as previously reported by Anastasakis and Piper (1991) in the Western Hellenic trench.

We carried out a high resolution $(1 \mathrm{~mm})$ multidisciplinary study of turbidite beds within sapropel S1, in a gravity core (CALA 21) collected in the Ionian Sea, using grain size, physical properties, micropaleontolog ical, XRF elemental, and organic geochemical analyses. Three additional cores collected in different physiographic settings of the CA, showing similar sapropel S1 interruptions, are included as Supplementary materi al (SM1). The purpose of our study was to characterize the mass flow units within the sapropel S1, define as accurately as possible their age and the recurrence time, and deduce likely triggering mechanisms for their deposition.

\section{Tectonic setting}

Core CALA 21 was collected in the inner CA, a subduction complex due to the SE NW Africa/Eurasia plate convergence (Fig. 1), occurring presently at the very slow rate of about $5 \mathrm{~mm} \mathrm{a}^{-1}$ or less (D'Agostino et al., 2008). Despite the slow present day plate convergence, subduction might still be active. In fact, tomographic images from central Calabria, show a continuous subducting slab (Neri et al., 2009) while seismic reflection profiles suggest active crustal compression and outward motion of the CA as a result of shortening in the accretionary wedge (Polonia et al., 2011).

The submerged portion of the CA consists of a NW thickening wedge of deformed sediments overlying the NW dipping basement (Cernobori et al., 1996; Polonia et al., 2011). Two distinct accretionary wedges bounded by the outer and inner deformation fronts, form the subduction complex. The outer wedge is a salt bearing complex characterized by frontal accretion, while, inwards, the pre Messinian clastic wedge is affected by underplating processes (Polonia et al., 2011). To the rear of the accretionary wedge the inner plateau shows both compressive and transtensive tectonic features. Complex faulting along an inner deformation front (the Calabria Escarpment), at the transition between the pre Messinian wedge and the Inner plateau, causes fluid flow and mud volcanism (Panieri et al., 2013).

The subduction complex is segmented across strike by NNW SSE transfer structures representing the shallow expression of slab tearing and STEP (Slab Transfer Edge Propagator after Govers and Wortel,
2005) faults located on both sides of the undetached slab (Neri et al., 2009). To the SW, slab tearing is marked by transtensive fault systems and sedimentary basins with two main STEP faults running from the Alfeo seamount to the Etna volcano and close to the Messina Straits region (Polonia et al., 2011, 2012 and reference therein). Close to CALA 21 coring site, a wide region of active deformation affects the off shore of the Crotone Capo Colonna region (Fig. 1). This tectonic pattern is related to deformation along a second major STEP fault system bounding the north eastern Ionian slab edge (Neri et al., 2012).

\section{Continental margin morphology and seismicity}

Multibeam and high resolution seismic data have been used to de fine the morphology of continental slopes and canyon systems offshore Calabria, characterized by intense geomorphic activity. Due to the high topographic gradients, the coastal areas are exposed to retrogressive erosion of the canyon heads yielding to sediment mass wasting and slope failures. The absence of major landslides at the base of the continental slopes suggests that gravitative failures occurred mainly as local processes, in the form of frequent and diffused debris flows (grain/mud flows) evolving downslope into turbidity flows (Morelli et al., 2011).

During Middle and Upper Pleistocene, the southernmost Apennines underwent tectonic uplift, which caused increased topographic steep ness, large volume sediment discharge, and mass transport deposits. Uplifted marine terraces in the CA (Antonioli et al., 2006) suggest that very high $(2.1 \mathrm{~mm} / \mathrm{yr})$ Holocene uplift rates in southwestern Calabria and deformation is equally balanced between regional and coseismic components (Ferranti et al., 2007).

Central and southern Calabria bear a historical record of destructive earthquakes often associated with tsunamis (Bottari et al., 1989; Piatanesi and Tinti, 1998; Boschi et al., 2000; Jacques et al., 2001; Galli and Bosi, 2003; CPTI working group, 2004; Tinti et al., 2004; Jenny et al., 2006). Despite the detailed earthquake catalogue (CPTI Working Group, 2004), knowledge of source parameters is still debated especially for those earthquakes possibly generated offshore.

The record of major historical earthquakes between the Messina Strait and Calabria since $91 \mathrm{BC}$, includes more than 25 earthquakes with $\mathrm{M}_{\mathrm{w}}>6$ (Galli and Bosi, 2003; CPTI Working Group, 2004; Galli et al., 2006). Only part of these events took place on the Ionian side of Calabria (CPTI Working Group, 2004) such as the AD 1638, AD 1744, AD 1832, AD 1836, AD 1947 and the seismic sequences of AD 1783. The frequent occurrence of tsunamigenic earthquakes, combined with evidence of mass wasting processes involving deposits of corresponding ages (Polonia et al., 2013a, 2013b), suggests a causal relationship between earthquakes and mass flows in historical times.

\section{Study material and methods}

The 5.34 m long CALA 21 gravity core (38 24.994 N, $1755.671 \mathrm{E}$ ) was collected at $2396 \mathrm{~m}$ water depth using a $1.2 \mathrm{t}$ gravity corer during the oceanographic cruise CALAMARE 08, onboard R/V CNR Urania (Fig. 1). The coring station is located on top of a structural high, which rises $300400 \mathrm{~m}$ above the surrounding area (Fig. 1). The site was chosen to study relationships between tectonics, fluid flow and sedimentation, in a setting securing a continuous long time section with a relatively low sedimentation rate, unlikely to be exposed to erosion caused by high energy processes.

The core was studied by multi proxy analyses including geophysics, sedimentology, physical properties, geochemistry, micropaleontology, mineralogy, radiometric dating and bulk sediment stable isotopic analysis.

Grain size analysis was carried out on samples collected every $1 \mathrm{~cm}$ within sapropel S1 and at lithological changes outside S1; samples were analyzed for the $0.042000 \mu \mathrm{m}$ fraction using a Beckman LS 230 laser 


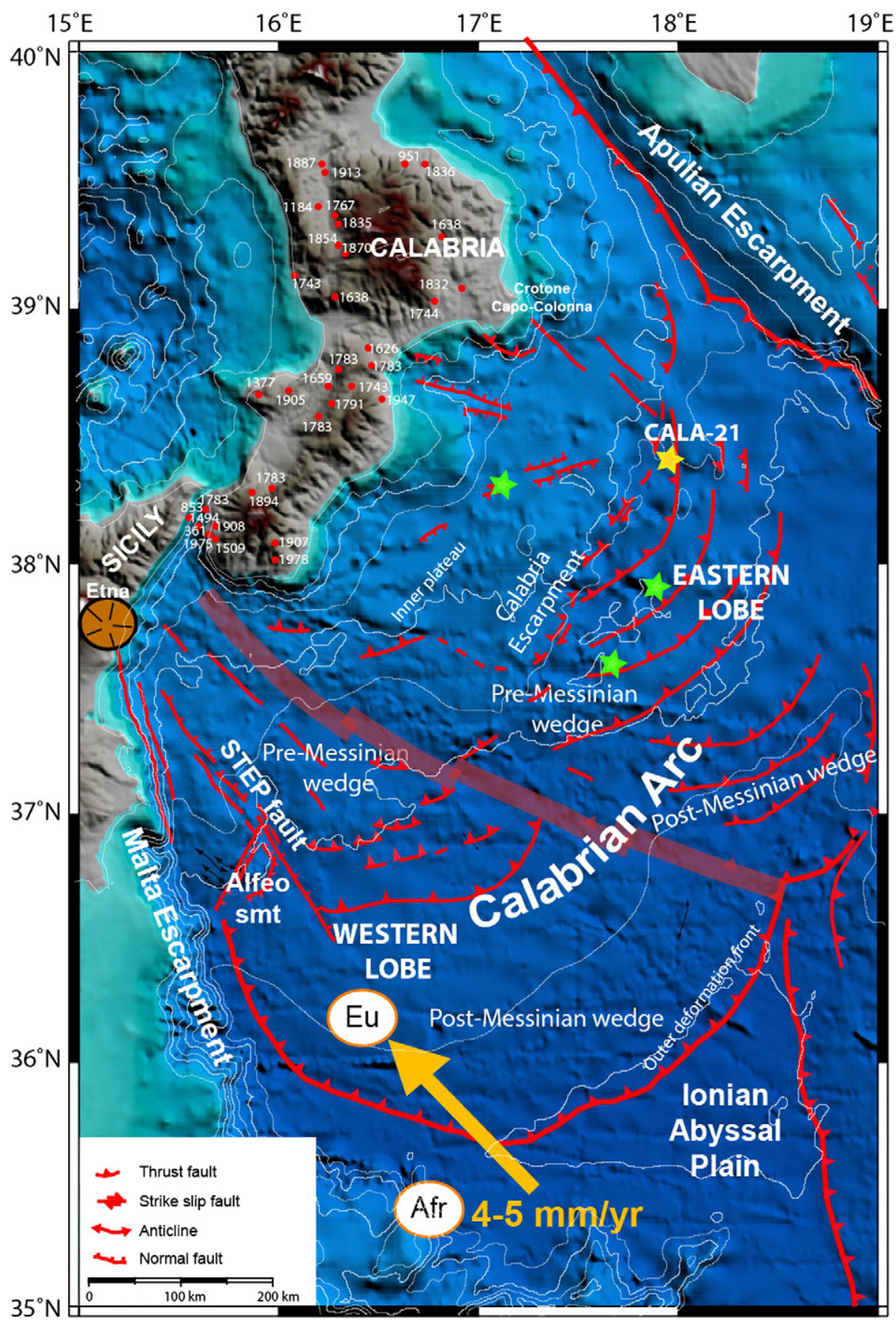

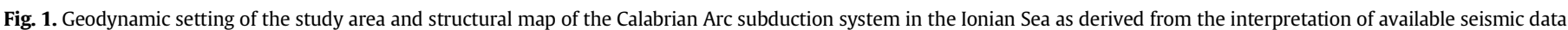

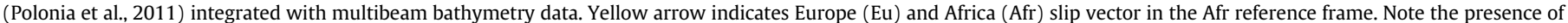

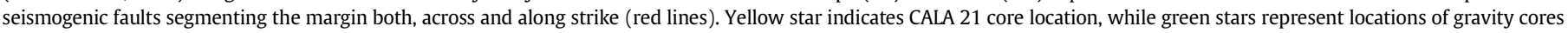
shown in Supplementary material S3. Epicenters of historical earthquakes (CPTI Working Group, 2004) are indicated by red circles.

coulter counter. Results were classified according to Friedman and Sanders' (1978) grain size scale.

Magnetic susceptibility was acquired at $1 \mathrm{~cm}$ sampling interval and integration time of $5 \mathrm{~s}$, using a Bartinghton (model MS2, $100 \mathrm{~mm}$ ring) susceptivity meter, equipped with a $100 \mathrm{~mm}$ ring.

$\mathrm{X}$ Ray images were collected using a constant potential radiographic unit (Gilardoni CPX M160), equipped with a metal ceramic tube head, at a $160 \mathrm{kV}$ max potential, using a be directional tube with $0.4 / 1.5$ bifocal, $4 / 10 \mathrm{~mA}$.

Elemental composition of core CALA 21 was analyzed using an Avaatech XRF core scanner, operating with both 10 and $50 \mathrm{kV}$ settings.
Measurements were performed every $1 \mathrm{~cm}$ along the whole core, while, within the sapropel $S 1$, resolution was increased to $1 \mathrm{~mm}$. The goodness of fit between XRF spectrum and processing model $\left(\chi^{2}\right)$ resulted $<3$. $\mathrm{R}$ mode factorial analysis was carried out on the XRF elemental data, after standardization through STATISTICA soft ware package, to detect relationships between different elements (Supplementary Material 2).

Nine key samples were used for organic geochemical analyses car ried out at ISMAR (Institute of Marine Sciences) CHN Lab on acidified sediment $(\mathrm{HCl}, 1.5 \mathrm{M})$ to remove carbonate fraction. Total organic carbon (TOC), total nitrogen (TN) and $\delta^{15} \mathrm{~N}$ were determined on untreated 
sediments. Analyses were performed using a Finnigan DeltaPlus mass spectrometer directly coupled to a FISONS NA2000 Element Analyzer.

Mineralogical analyses were carried out on selected samples using a Polarized Light Microscope (PLM) on grain mount (immersion oil $\mathrm{RI}=1.55$ ) and a scanning electron microscope with EDS attachment (SEM/EDS at Dipartimento di Scienze Biologiche, Geologiche e Ambientali, University of Bologna). The PLM allowed identification of main components (minerals and plant fragments), and the SEM/EDS was used to identify minerals and proportion among components and analyze glass shards (see Supplementary Material 3)

Micropaleontological analyses were performed on $>63 \mu \mathrm{m}$ size fraction. Subsamples of 0.5 or $1 \mathrm{~cm}$ thickness were obtained at major lithological and textural changes. The sub samples were weighed, washed, dried and studied. Planktonic foraminifera were identified and semi quantified, while benthic foraminifera were picked, identified and counted; species were grouped considering their bathymetric distribution and test morphology (Table 1).

Accelerator mass spectrometry (AMS) radiocarbon dating was performed on handpicked planktonic foraminifera with no evidence of carbonate overgrowth or pyritization (Table 2). We selected samples in the sapropel S1 units bracketing the turbidite beds, 1 and $2 \mathrm{~cm}$ above the top of the turbidites to avoid reworked tests possibly occurring close to the base of the turbidite. About $56 \mathrm{mg}$ of specimens $>150 \mu \mathrm{m}$ in size from $1 \mathrm{~cm}$ thick samples was studied. The AMS analyses were
Table 2

Accelerator mass spectrometry (AMS) radiometric dating results for samples within sapropel beds $S 1-2,-5,-7$ and -9 bracketing turbidite beds.

\begin{tabular}{llll}
\hline Sample name & Lab. no. & Age ${ }^{14} \mathrm{C}$ & Sapropel unit \\
\hline CALA 21 V 27-27.5 cm & Poz-52729 & $6040 \pm 40$ BP & S1-9 \\
CALA 21 V 31.5-32 cm & Poz-53215 & $6730 \pm 40$ BP & S1-8 \\
CALA 21 V 46-46.5 cm & Poz-52731 & $7860 \pm 60$ BP & S1-5 \\
CALA 21 V 62-63 cm & Poz-52732 & $8920 \pm 70$ BP & S1-2 \\
\hline
\end{tabular}

performed at the Poznań Radiocarbon Laboratory Foundation of the Adam Mickiewicz University (Poland).

Age modeling was made using the P_Sequence (a Bayesian model of deposition) implemented in the computer program OxCal 4.1, which as similates sedimentation as a random process following a Poisson law (Bronk Ramsey, 2008). The input parameters to generate the P_Sequence model are the uncalibrated ${ }^{14} \mathrm{C}$ ages and respective $\Delta \mathrm{R}$. An average regional reservoir age of $147 \pm 33 \mathrm{yr}$ was calculated as weighted mean including $2 \Delta \mathrm{R}$ values of published reservoir ages in the surround ing areas (Calib database at http://calib.qub.ac.uk/marine/). The regular ity of sedimentation is defined by the k parameter with the higher values of $\mathrm{k}$ reflecting smaller variations in sedimentation rate (Bronk Ramsey, 2008). We used $\mathrm{k}=3.0$, assuming that pelagic sedimentation is rather constant during sapropel deposition. Finally, the model calculated the

Table 1

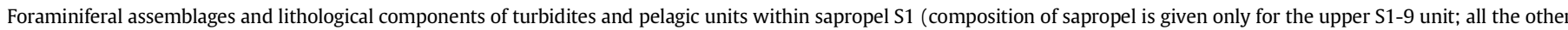

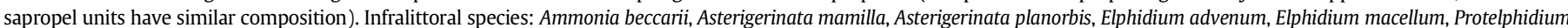

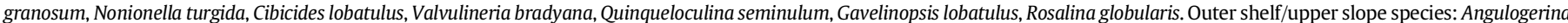

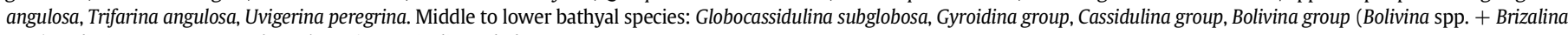
spp.), Bulimina group. Lower abyssal species: Articulina tubulosa.

\begin{tabular}{|c|c|c|c|}
\hline & Planktonic foraminifera & Benthonic foraminifera & Mineralogy \\
\hline S1-9 & $\begin{array}{l}\text { G. ruber group; G. sacculifer, G. tenellus, } \\
\text { G. bulloids, G. glutinata, O. universa }\end{array}$ & Barren & $\begin{array}{l}\text { Aggregates of organic matter, detritic material less than } 5 \% \\
\text { or absent }\end{array}$ \\
\hline TS-8 & Barren & Barren & $\begin{array}{l}\text { No abundant sediment fraction }>63 \mu \mathrm{m} \text {. Aggregates of } \\
\text { siliciclastic and carbonatic material. }\end{array}$ \\
\hline
\end{tabular}

TS-7 Scarce (G. ruber group, G. bulloides)

S1-7

TS-6 Scarce (T. quinqueloba)

S1-6

TS-5 Scarce (T. quinqueloba)

S1-5

TS-4 Very scarce (G. ruber group, T. quinqueloba)

S1-4

TS-3 Very scarce (T. quinqueloba, G. bulloides)

S1-3

TS-2 Very scarce (T. quinqueloba)

S1-2

TS-1b Very scarce(T. quinqueloba)

TS-1a Scarce/very scarce (T. quinqueloba, G. bulloides)
Benthic assemblages with displaced (infralittoral, outer shelf) and middle to lower bathyal species.

Benthic assemblages with displaced (infralittoral) and middle to lower bathyal species (similar to T1-T3 in Polonia et al., 2013a, b).

Benthic assemblages with displaced infralittoral and middle to lower bathyal species.

Benthic assemblages with displaced infralittoral and middle to lower bathyal species.

Benthic assemblages with displaced infralittoral and middle to lower bathyal species.

Benthic assemblages with displaced (infralittoral outer shelf) and middle to lower bathyal species.

Benthic assemblages with displaced (infralittoral, outer shelf) and middle to lower bathyal species. Benthic assemblages with displaced (infralittoral, outer shelf) and middle to lower bathyal species
No abundant sediment fraction $>63 \mu \mathrm{m}$ Few plant fragments.

Quartz, feldspar, mica, pyrite Few plant fragments.

Quartz, feldspar, mica, pyrite Few plant fragments.

Quartz, feldspar, few rhyolitic glass shard (unknown origin), aggregates of siliciclastic and carbonatic material Few plant fragments.

Quartz, few feldspars, plagioclase, mica, few rhyolitic glass shard (unknown origin) and abundant pyrite. Few plant fragments.

Abundant irregular micritic grains Few plant fragments.

Quartz, feldspar and large biotite fragments Few plant fragments.

Quartz, feldspar, mica (biotite and muscovite) and abundant pyrite in framboids Few plant fragments. 
age of each corrected depth and generated the $95.4 \%$ probability age distribution $(2 \sigma)$.

\section{Results}

\subsection{Multiproxy analysis of CALA 21 sediment core}

Sediment structure and composition of the core CALA 21 sequence show a significant change about $284 \mathrm{~cm}$ below the core top, a level also marked by a sharp change in magnetic susceptibility (Fig. 2). Above this level, the sedimentary sequence consists of yellowish and brownish bioturbated hemipelagic sediments interbedded with $\mathrm{cm}$ thick, fine grained turbidites (light green color in Fig. 2), tephra and the sapropel S1 unit.

The lower part of the core (below $284 \mathrm{~cm}$ ) is made of a silty clay unit containing differently colored sediments, previously described as mud breccia patchy/cloudy facies (Panieri et al., 2013) and related to repetitive fluid outflow and mud volcanism in the accretionary wedge during Pliocene and Pleistocene.

In this work, we analyzed the upper part of core CALA 21, where no mud breccia is present. In particular, we focused on the structure and composition of the Sapropel S1 unit, which show a succession of "anom alous" sediment intervals interrupting sapropel deposition.

\subsection{Sedimentary facies}

\subsubsection{Sapropel S1}

A $40 \mathrm{~cm}$ thick interval, from about 60 to $100 \mathrm{~cm}$ below the core top, showing alternate dark and light bands, corresponds to sapropel S 1 (Fig. 2). Within this interval, nine light gray beds interrupt the olive gray sapropel S 1 into nine sub sapropel units (S1 1 to S1 9). The sapropel sub units, cumulating a total thickness of $27.5 \mathrm{~cm}$, contain TOC between $1.88 \%$ at the base and $1.26 \%$ at the top. Although these values are below the $2 \%$ distinctive limit of sapropel layers (Kidd et al., 1978), they are eight times higher than non sapropel sediments (0.21 0.32\%).

The base of sapropel S1 is defined by increased Ba elemental intensi ties, in agreement with depth dependent Corg content within S1 sediments (Murat et al., 1990; De Lange et al., 2008), while its top is identified by a Mn peak as proposed by De Lange et al. (2008) and by pe culiar foraminifera associations (Table 1). Abundant pyrite is present within S1, a common occurrence in anoxic sapropels and sapropelic sediments.

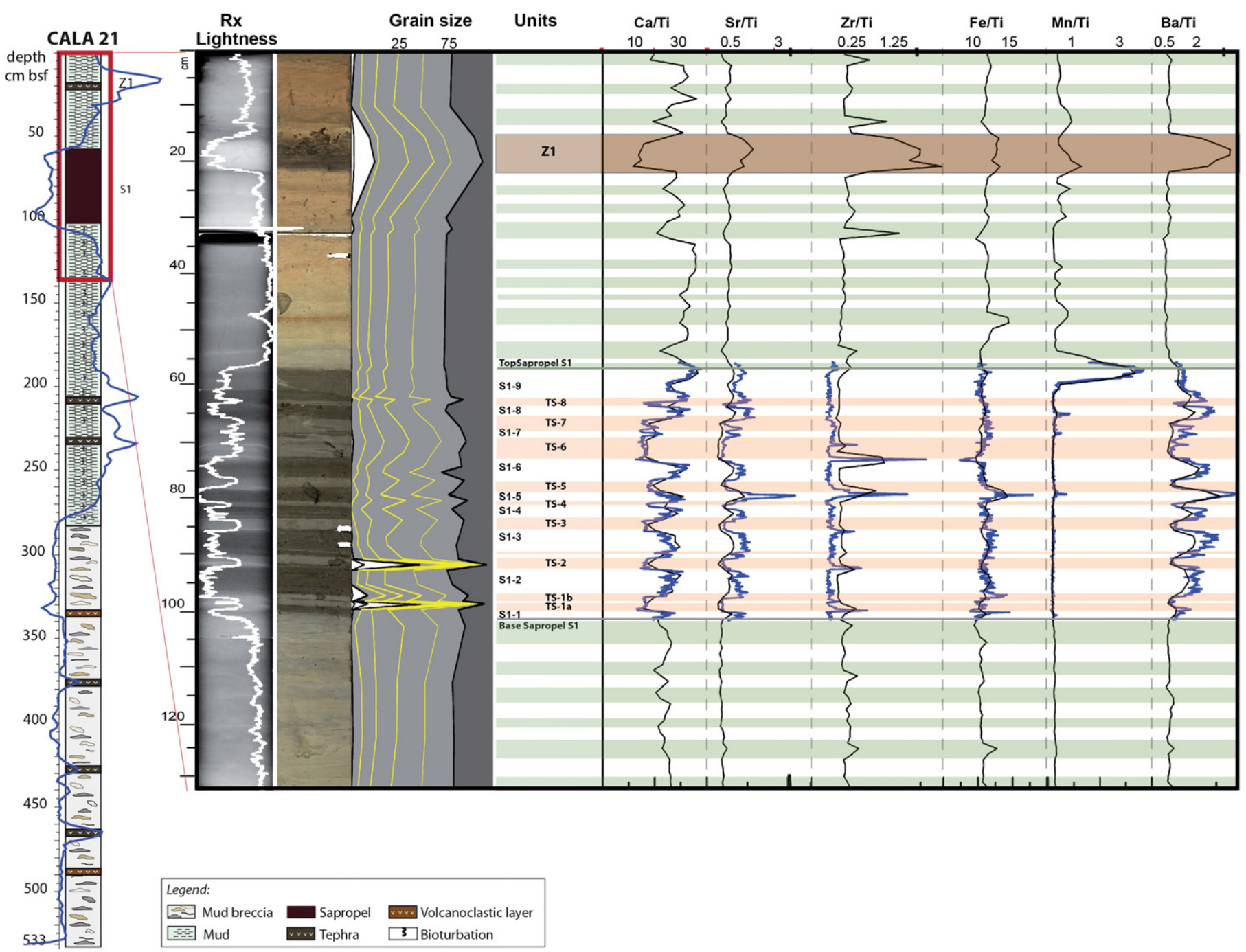

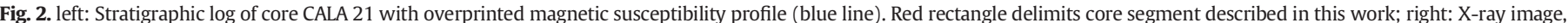

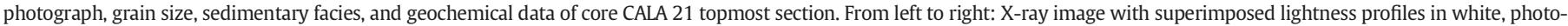

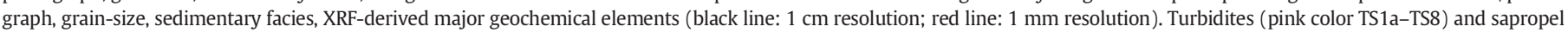
units (white units S1-1/S1-9) are indicated. Above and below sapropel S1, turbidite beds are indicated in green, while tephra layer Z1 is indicated in brown. 
Other distinctive sapropel characters in CALA 21 core are: a) low mag netic susceptibility; b) biogenic composition with abundant planktonic foraminifera typical of recent Mediterranean Sea deposits, pteropods and absence of benthic foraminifera (Table 1 and Fig. 3); c) scarcity or absence of lithic fragments; d) dark uniform beds with small black patches of organic matter in X ray images; e) relatively high $\mathrm{Ba}, \mathrm{S}, \mathrm{Ca}$ and $\mathrm{Sr}$ elemental contents; and f) low $\delta^{15} \mathrm{~N}$ values, between 1.119 and 1.84 (Table 3).

\subsubsection{Turbidite beds (TS) within sapropel S1}

Multi proxy analyses of sediment samples identified nine major S1 interruptions (TS 1a/TS 8) represented by 1 to $5 \mathrm{~cm}$ thick, light gray units with a sharp base, some of them marked by small peaks in mag netic susceptibility relative to the low background typical of sapropel values (Fig. 2) as well as diagnostic peaks in $\mathrm{Zr}$ elemental concentration. On $\mathrm{X}$ ray images, sapropel interruptions appear as lighter (denser) bands bounded by sharp basal contacts, cross stratification in the basal part and planar lamination close to their top.

Turbidite beds show: a) coarse basal layers; b) polygenetic mixture of lithic clasts, plant fragments and displaced benthic foraminifera supplied from several sources and bathymetric ranges (Table 1); d) sharp $\mathrm{Zr}$ enrichment at the base decreasing upwards; and e) higher TOC contents $(0.610 .65 \%)$ relative to the background units above and below the sapropel. The enhanced Corg content in the turbidites might mean that the reworked material is contemporaneous and comes from shallower sites containing less OM than in situ correlative S1. Alternatively, it might be due to a mixture of transported OM poor slumping material and sapropelic sediment.

The sand fraction in the turbidite beds ranges from $0.27 \%$ (silty turbidites) to $48.8 \%$ (sandy turbidites) and is constituted by quartz, feldspar, mica, pyrite, aggregates of detrital and carbonate material, and plant fragments (Table 1).

\subsubsection{Sediment core below and above sapropel $S 1$}

Sediments above and below sapropel S1 consists of yellowish (above) and brownish (below) hemipelagic sediments alternating with $\mathrm{cm}$ thick fine grained turbidites and a tephra layer marked by high magnetic susceptibility and geochemical anomalies (Fig. 2).

On $\mathrm{X}$ ray images, hemipelagic intervals are represented by dark bands, with black organic matter associated with increased Ca elemental concentration.

Turbidite beds are less evident outside sapropel S1 because they are not associated with sharp color and grain size changes. Above and below sapropel S1, turbidites were defined thanks to geochemical, mineralogical and micropaleontological proxies combined with $\mathrm{X}$ ray imaging.

On X ray images, turbidites are marked by light bands with sharp and reflective basal surfaces. Turbidite layers display darker colors (gray below S1 and brown above S1) relative to hemipelagic deposits, small peaks of $\mathrm{Zr}$ at their base, and lower content of $\mathrm{Ca}$ and $\mathrm{Sr}$. The up ward decrease in $\mathrm{Zr}$ starting from the base of each turbidite indicates upward decrease in the grain size (i.e., normal size grading). During micropaleontogical observations many broken specimens filled by $\mathrm{CaCO}_{3}$ and/or pyrite were found. Samples collected within turbidite beds contain mica and pyrite, a high percentage of lithic components and small size foraminifera, suggesting hydraulic sorting. This evidence suggests that these layers might be deposited from relatively low energy turbidite tails, implying that before and after sapropel S1 time period, mass flow processes had a decreased overall energy.

\subsubsection{Tephra layer $Z 1$}

Tephra layer Z1 (Fig. 2) is a sand size accumulation of glass and min eral fragments with high contents of large ion lithophile and high field strength elements (e.g., Rb, Sr, Ba and $\mathrm{Zr}$ ). SEM/EDS microanalysis and mineralogical observations (Supplementary Material 3) show that this tephra layer has a composition similar to the products of the AD 79 Somma Vesuvius volcano (Wulf et al., 2008; Zanchetta et al., 2011).

\subsection{Organic geochemical analysis}

Organic geochemical analyses including TOC, $\mathrm{C} / \mathrm{N}$ (atomic) ratio, $\delta{ }^{15} \mathrm{~N}$ and $\delta{ }^{13} \mathrm{C}$ were used to gather information on the source of organic
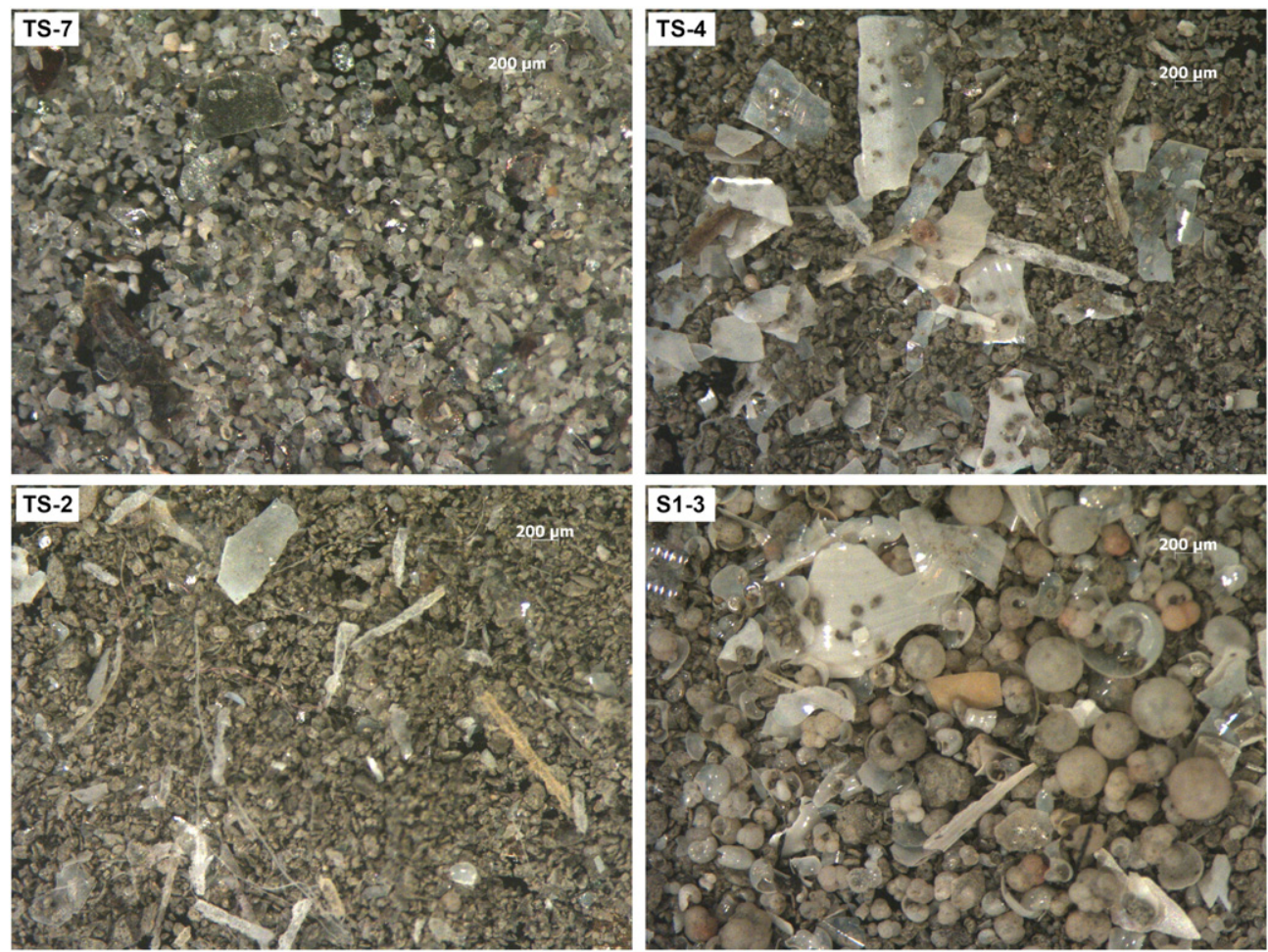
Table 3

Organic carbon data.

\begin{tabular}{|c|c|c|c|c|c|c|c|c|c|}
\hline & Core depth & $\mathrm{mg}$ & Ntot\% & $\% \mathrm{OC}$ & $\delta^{13} \mathrm{C}$ & $\%$ Ctot & \%Cinorg & $\mathrm{C} / \mathrm{N}$ atomic & $\mathrm{d} 15 \mathrm{~N}$ \\
\hline $\begin{array}{l}\text { Above S1 } \\
\text { (pelagic) }\end{array}$ & 55.0 & 7.519 & 0.061 & 0.32 & 23.09 & 4.37 & 4.05 & 6.1 & 4.25 \\
\hline S1-9 & 60.0 & 8 & 0.139 & 1.26 & 22.74 & 5.50 & 4.24 & 10.6 & 1.48 \\
\hline S1-9 & 62.0 & 9.071 & 0.144 & 1.35 & 22.75 & 5.42 & 4.07 & 10.9 & 1.21 \\
\hline TS-7 & 68.0 & 9.198 & 0.078 & 0.65 & 24.63 & 3.40 & 2.75 & 9.7 & 3.01 \\
\hline TS-3 & 84.0 & 11.165 & 0.074 & 0.61 & 24.68 & 3.36 & 2.76 & 9.6 & 2.80 \\
\hline S1-3 & 87.0 & 8.655 & 0.167 & 1.74 & 22.89 & 5.59 & 3.85 & 12.2 & 1.19 \\
\hline TS-2 & 91.0 & 9.963 & 0.073 & 0.61 & 24.42 & 3.21 & 2.60 & 9.6 & 2.31 \\
\hline S1-2 & 95.0 & 7.749 & 0.173 & 1.88 & 23.34 & 5.69 & 3.81 & 12.7 & 1.84 \\
\hline $\begin{array}{l}\text { Below S1 } \\
\text { (pelagic) }\end{array}$ & 119.0 & 11.743 & 0.043 & 0.21 & 23.86 & 3.78 & 3.57 & 5.7 & 3.08 \\
\hline
\end{tabular}

matter (marine vs. terrestrial, according to Ogrinc et al., 2005; Lamb et al, 2006). C/N (atomic) ratio vs $\delta^{13} \mathrm{C}$ (Table 3, Fig. 4) data are clustered in three groups including sapropel and turbidite units as well as back ground sediments above and below sapropel S1 (Fig. 4).

Sapropel sediments and samples immediately below and above S1 show a pattern consistent with a marine provenance, in good agreement with what was previously reported (Higgins et al, 2010 and references therein). Moreover, samples collected in hemipelagic units above and below sapropel S1 show TOC contents similar to that described by Polonia et al. (2013b) for pelagic sediments. On the other hand, turbidite layers within sapropel S1 show intermediate values of $\mathrm{C} / \mathrm{N}$ vs $\delta^{13} \mathrm{C}$, suggesting a mixture of OM poorer slumping material and sapropel derived inputs.

\subsection{Accelerator mass spectrometry (AMS) radiocarbon dating}

Radiocarbon dating carried out on foraminifera tests from the S1 sapropelic sediments is summarized in Table 2. Uncalibrated ages within S1 range from $8920 \pm 70 \mathrm{BP}$ (unit S2) to $6040 \pm 40 \mathrm{BP}$ (unit S9 close to the sapropel top). These dates are in good agreement with published radiocarbon dating of S1 defined on the basis of Ba and TOC (start at
$9.770 \pm 350{ }^{14} \mathrm{C}$ yr) and on the Ba and $\mathrm{Mn}$ (end at $5.710 \pm 440{ }^{14} \mathrm{C}$ yr) content at all water depths (De Lange et al., 2008).

Total thickness of pelagic S1 units in our core is $27.5 \mathrm{~cm}$. If we assume no erosion during the turbidite emplacement and a constant sedimentation rate during S1 deposition, the age of each turbidite bed can be determined by the thickness of sapropel sub units (see following Section 5.5) or performing an age modeling.

\subsection{Age model}

The age of each turbidite bed was defined through age modeling using OxCal software, which combines age determinations from AMS dated samples with information about deposition process (Bronk Ramsey, 2008). This allows defining chronologies and interpolate between dated levels in the deposition sequence, taking into account propagation errors (Bronk Ramsey et al., 2010).

Before modeling turbidite emplacement, we have used dated levels to obtain a new estimate of the sapropel S1 age. Our results suggest that S1 started between 10,800 and $9800 \mathrm{ka} \mathrm{BP}$ and ended between 6270 and $5630 \mathrm{ka} \mathrm{BP}$, with higher probability ages of $10.26 .0 \mathrm{ka}$ cal $\mathrm{BP}$ (Table 4 and Fig. 5). If we include dating errors, we deduce that the sapropel in our core lasted between 3530 and 5170 years. During such

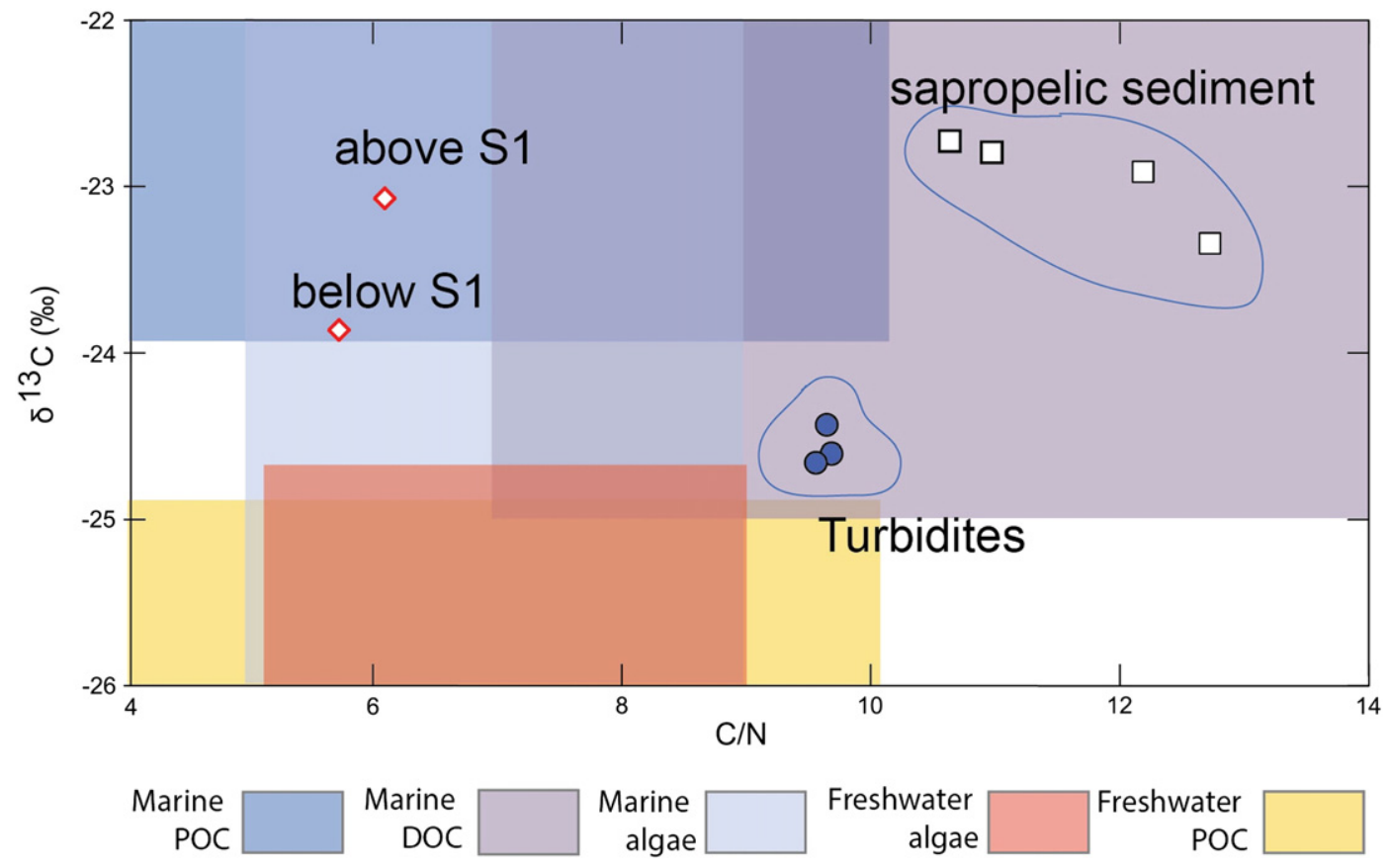

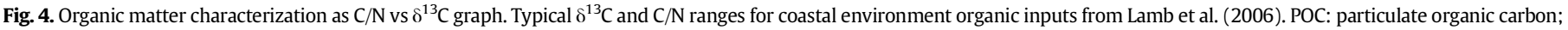

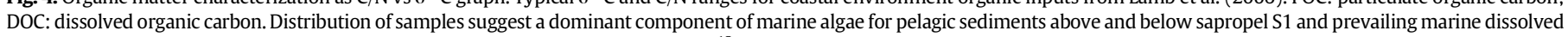

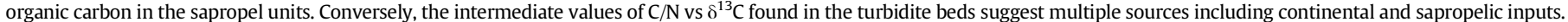


Table 4

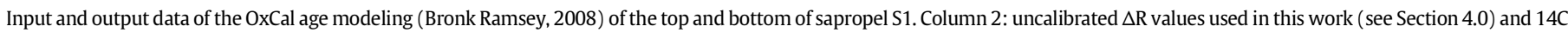

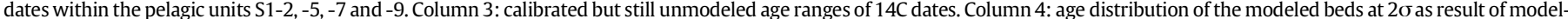

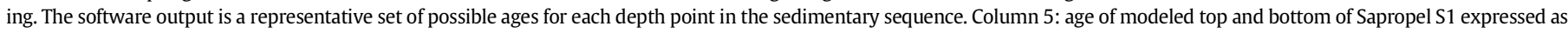
years BP.

\begin{tabular}{|c|c|c|c|c|c|c|c|c|}
\hline \multirow{3}{*}{$\begin{array}{l}1 \\
\text { Name }\end{array}$} & \multirow{3}{*}{$\begin{array}{l}2 \\
\text { Uncalibrated } \\
\text { (BP) }\end{array}$} & \multirow{2}{*}{\multicolumn{3}{|c|}{$\begin{array}{l}3 \\
\text { Unmodeled (BC/AD) }\end{array}$}} & \multirow{2}{*}{\multicolumn{3}{|c|}{$\begin{array}{l}4 \\
\text { Modeled (BC/AD) } \\
\end{array}$}} & \multirow{3}{*}{$\begin{array}{l}5 \\
\text { Age of top and bottom of Sapropel S1 } \\
\text { (BP) }\end{array}$} \\
\hline & & & & & & & & \\
\hline & & From & To & $\%$ & From & To & $\%$ & \\
\hline Curve Marine09 & $147 \pm 33$ & 80 & 214 & 95.4 & 84 & 219.5 & 95.4 & \\
\hline \multirow{3}{*}{\multicolumn{9}{|c|}{$\begin{array}{l}\Delta \text { R LocalMarine } \\
\text { P_Sequence } \\
\text { CALA } 21\end{array}$}} \\
\hline & & & & & & & & \\
\hline & & & & & & & & \\
\hline \multicolumn{5}{|l|}{ S1 TOP } & 4271 & -3630 & 95.4 & \multirow[t]{5}{*}{$6278-5625$} \\
\hline R_Date S1-9 & $6040 \pm 40$ & 4471 & -4251 & 95.4 & 4472 & -4252 & 95.4 & \\
\hline R_Date S1-7 & $6730 \pm 40$ & 5286 & -5015 & 95.4 & 5286 & -5023 & 95.4 & \\
\hline R_Date S1-5 & $7860 \pm 60$ & 6379 & -6066 & 95.4 & 6342 & -6041 & 95.4 & \\
\hline R_Date S1-2 & $8920 \pm 70$ & 7643 & -7305 & 95.4 & 7657 & -7322 & 95.4 & \\
\hline S1 BASE & & & & & 8812 & -7801 & 95.4 & $10.802-9796$ \\
\hline
\end{tabular}

time interval, $27.5 \mathrm{~cm}$ of anoxic sediments were deposited, which gives a sedimentation rate ranging between 5.32 and $7.79 \mathrm{~cm} / \mathrm{ka}$. If we consider the maximum of the age probability distribution (i.e. 10.2 $6.0 \mathrm{ka}$ cal BP) the average sedimentation rate is $6.5 \mathrm{~cm} / \mathrm{ka}$. Estimates of post sapropel pelagic sedimentation rate in the deep Ionian abyssal plain range between $6.8 \mathrm{~cm} / \mathrm{ka}$ and $9.7 \mathrm{~cm} / \mathrm{ka}$ (Polonia et al., 2013a). This suggests a relatively constant deposition during the Holocene in our cores, although previous works in other regions of the Ionian Sea re ported lower sedimentation rates during sapropel deposition $(23 \mathrm{~cm} / \mathrm{ka}$, Langereis et al., 1997; 24 cm/ka Crudeli et al., 2006; $24 \mathrm{~cm} / \mathrm{ka}$ De Lange et al., 2008).

The age of S1 (top and bottom) was then used to estimate the timing of each turbidite emplacement through the accurate determination of sapropel unit thickness between successive turbidite beds. This

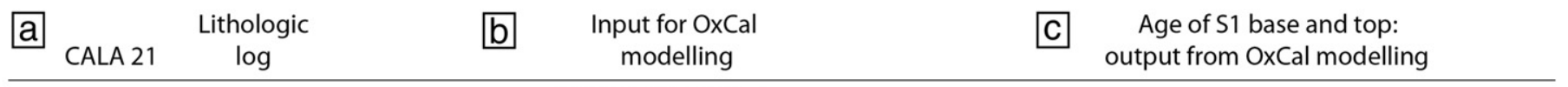

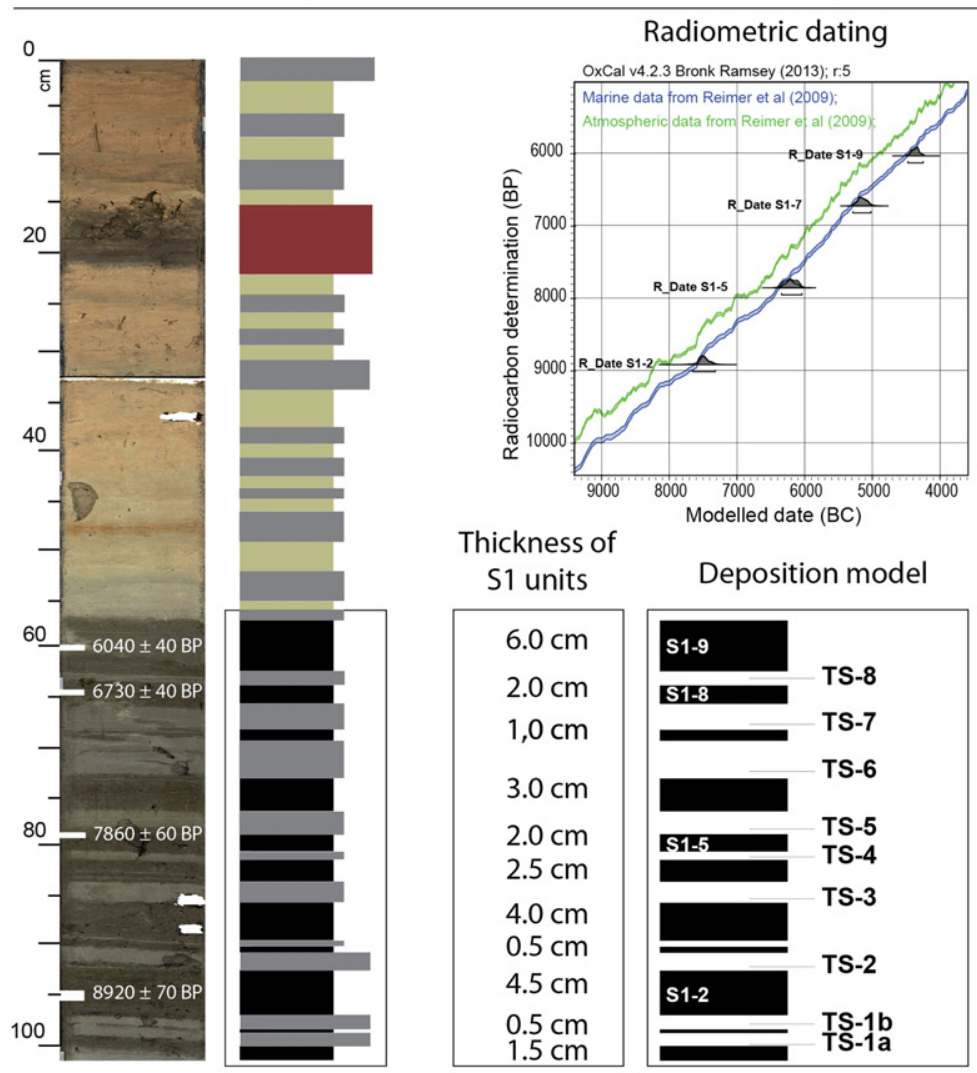

\begin{tabular}{l}
\hline Legend: \\
Tephra $\square$ Turbidite $\square$ Sapropel $\square$ Hemipelagite
\end{tabular}

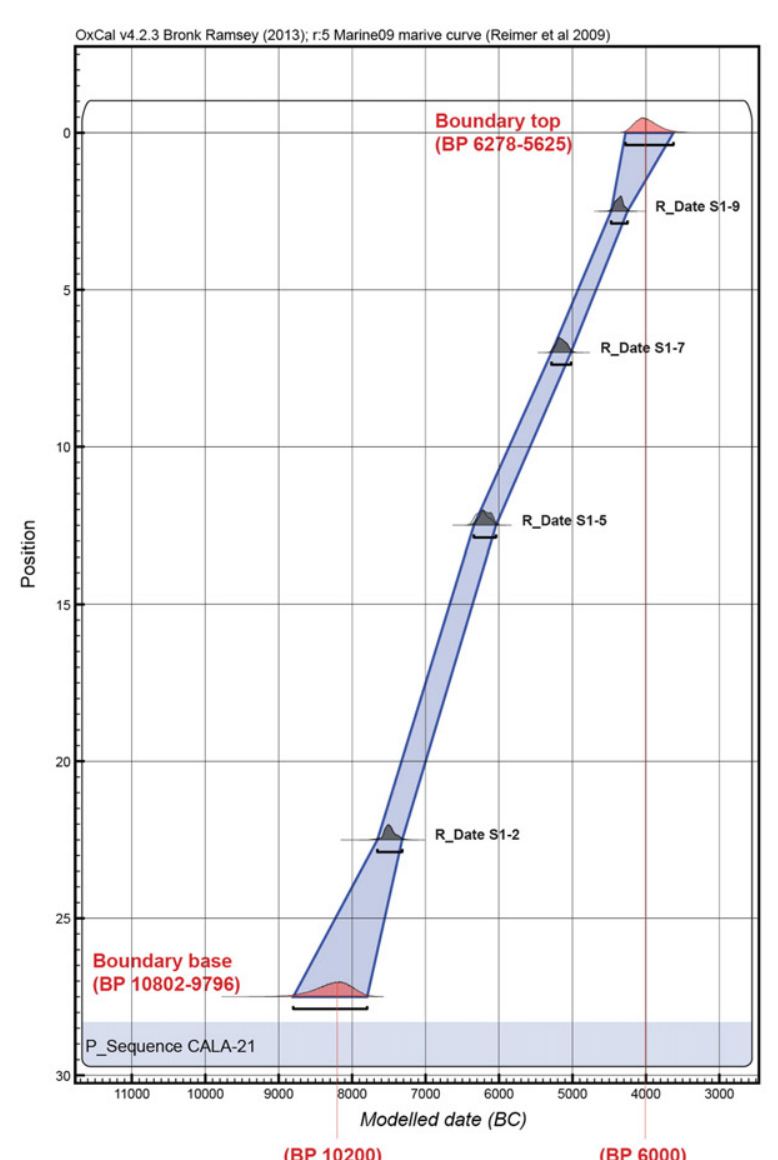

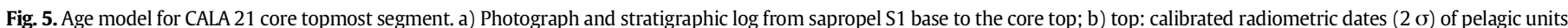

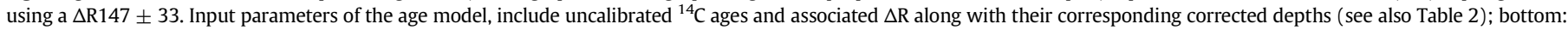

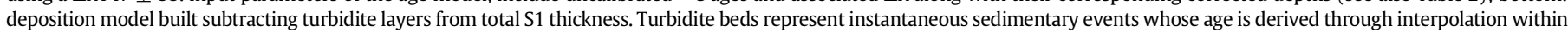
OxCal model (see results in Table 4); c) output data of OxCal age modeling (Bronk Ramsey, 2008) of the sapropel S1 age. See Table 4 for more details on age modeling. 
thickness can be converted in time intervals using our sedimentation rate estimates. If we consider the error propagation of radiometric dating, an error bar associated to each turbidite bed could be obtained using minimum and maximum sedimentation rates. For the sake of simplicity, we prefer to consider in this analysis the average sedimentation rate in order to obtain the mean interval between successive turbidite beds and the age of each resedimented unit within S1 (Table 5 column 1 ).

Given the errors associated to each calibrated radiocarbon date and their propagation, we had to take into account all the information about depositional processes contained in our multi proxy analysis to refine our chronology and interpolate between dated levels. For this purpose, we built an age model with OxCal software (Bronk Ramsey, 2008), that included information on the deposition process and accounted for deposition order and depth of each sapropel unit, derived subtracting the thickness of each turbidite from that of the total core (Fig. 5). In this way, we built a deposition model where the base and the top of sapropel S1 were defined through a detailed analysis of the core, and their ages estimated through probabilistic distribution of the ages in the model. The P_Sequence used to build the age model, assimilates sedimentation as a random process where the geological events ("boundaries") correspond to the instantaneous mass flows interrupting pelagic sedimentation. Each turbidite is considered an element of a progressing time sequence without overlaps and with no dating information associated with them. When AMS dating on pelagic units was introduced in the model, the software estimated the turbidite age distribution (distribution of the boundaries) at $2 \sigma$, based on their stratigraphic depth of emplacement within the background sequence.

Table 5 (column 2a) summarizes the output of our OxCal modeling. Considering the maximum in the probability distribution within $2 \sigma$, we obtained an age for each turbidite bed (Table 5 column 2b). Discrepancies between ages derived using these methods, i.e., simple averaging in (column 1 of Fig. 5) and probabilistic model (column 2 of Fig. 5), are related to a more accurate accounting of error propagation in OxCal which gives in output a probability density function for each point in the model. Moreover, the P_Sequence used for age modeling considers a random distribution of sedimentation within pelagic units, which is not the case for that obtained by averaging radiometric ages.

Both methods suggest that the recurrence time of resedimented units is not constant, and the interval between two successive turbidite beds varies from about 100 to $700 \mathrm{yr}$.

\section{Table 5}

Age of turbidite beds within sapropel S1 deduced through accurate determination of the thickness of sapropel units between successive turbidite beds and sedimentation rate (column 1) and OxCal age modeling (column 2).

\begin{tabular}{|c|c|c|c|}
\hline \multirow[b]{2}{*}{$\begin{array}{l}\text { TOP S1 } \\
\text { (kyr cal BP) }\end{array}$} & \multirow{2}{*}{$\begin{array}{l}\text { (1) } \\
\text { Age of turbidites deduced } \\
\text { through sapropel } \\
\text { sediment thickness and } \\
\text { sedimentation rate } \\
\text { Age } \\
(\text { Cal BP) } \\
6000 \\
\text { (This study: sed. rate } \\
\text { within } \mathrm{S} 1=0.065 \mathrm{~mm} / \mathrm{yr} \text { ) }\end{array}$} & \multicolumn{2}{|c|}{$\begin{array}{l}\text { (2) } \\
\text { Age of turbidites deduced } \\
\text { through OxCal age modeling } \\
\text { 'Modeled Age } \\
\text { (Cal BP) }\end{array}$} \\
\hline & & $\begin{array}{l}(2 a) \\
6000 \\
\text { (This study) }\end{array}$ & $\begin{array}{l}(2 \mathrm{~b}) \\
\text { TS higher } \\
\text { probability ages } \\
\text { from age modeling }\end{array}$ \\
\hline TS-8 & 6925 & $7195-6513$ & 6950 \\
\hline TS-7 & 7225 & 7853-7053 & 7150 \\
\hline TS-6 & 7375 & $8220-7263$ & 7850 \\
\hline TS-5 & 7835 & 8368-7798 & 8180 \\
\hline TS-4 & 8135 & $9085-8117$ & 8350 \\
\hline TS-3 & 8515 & $9447-8367$ & 9030 \\
\hline TS-2 & 9205 & $9601-8936$ & 9400 \\
\hline TS-1b & 9875 & $10200-9462$ & 9620 \\
\hline TS-1a & 9970 & 10200-9963 & 10150 \\
\hline $\begin{array}{l}\text { Bottom S1 } \\
\text { (kyr cal BP) }\end{array}$ & 10200 & 10200 & \\
\hline
\end{tabular}

\section{Discussion}

The well defined stratigraphic position, its synchronicity, composition and basin wide occurrence in the Mediterranean Sea, make sapropel S1 a stratigraphic key bed useful to study high energy anomalous sedimentary events in the Africa/Eurasia convergence zone. For this reason, the analy sis of turbidite beds within S1 carried out in this work may give insights for deciphering relationships between tectonics and sedimentation in a well defined chrono stratigraphic framework.

Resedimented units within S1 stand out in the sedimentary record because they show marked contrasts in color and composition (geochemistry, TOC, mineralogy and foraminiferal associations) relative to the background. The high resolution multidisciplinary analysis of in situ and resedimented units suggests that sapropel interruptions are made of terrigenous turbidite deposits, derived from different sources and bathymetric ranges, including the continental shelf and slope.

Sediment remobilization may be driven by a number of mechanisms, such as storms (Mulder et al., 2001), climate changes and related eustatic sealevel fluctuations (Weaver and Kuijpers, 1983), cascading currents (Shanmugam, 2013), hyperpycnal flows (Mulder et al., 2003), volcanic explosion and/or collapse (Urgeles et al., 1999), gas hydrate dissociation (Rothwell et al., 1998), mud volcanism (Panieri et al., 2013), tsunami waves (Polonia et al., 2013b) and seismic shaking (Goldfinger et al., 2012; Polonia et al., 2013a) or by a combination of these processes.

\subsection{Turbidites and seismic triggering}

To discriminate between different triggering mechanisms for mass flow deposits, a multidisciplinary/multi proxy analysis is mandatory.

In core CALA 21, hyperpycnal flows and bottom currents are not likely mechanisms for triggering turbidity currents, because of the peculiar physiographic setting of the coring site. In fact, core CALA 21 was collected $100 \mathrm{~km}$ offshore the Calabria shelf, and more than $300 \mathrm{~km}$ from the Greek coasts, on top of a tectonic high, $300400 \mathrm{~m}$ above the surroundings, too deep and isolated from canyon systems and the basin floor to be supplied by fluvial inputs, storms and bottom currents.

Another important point is that the occurrence of hyperpycnal flows usually decreases if weather becomes wetter, as during sapropel S1 deposition, because of enhanced vegetation cover, that protects emerged lands from erosion and reduces particle load (Mulder et al., 2003). In addition, at least the upper part of sapropel S1 corresponds in time to the maximum flooding of river valleys following the late Pleistocene Holocene transgression. Rising sealevel would have increased the distance of the continental slope from river mouths causing minimum delivery of suspended sediments to the open sea (sediments may have been largely trapped in bedrock valleys before reaching the shelf edge). Moreover, low rates of sediment discharge on the slopes of the Calabrian margin do not favor slumping related to sediment loading.

Mass flow events may be influenced by glacio eustatic oscillations (Weaver and Kuijpers, 1983; Rothwell et al., 2000). However, in our case such effect is unlikely, because the Holocene sealevel curve (Lambeck et al., 2004) does not show significant variations at frequen cies as high as $500 \mathrm{yr}$ or less.

Mud volcanism may also be excluded as a triggering mechanism, because its diagnostic facies, i.e., mud breccia patchy cloudy facies, is present only in the lower part of the core, and dates back to Pliocene Pleistocene time (Panieri et al., 2013). Moreover, the lack of planktonic foraminifera entrained from old formations, and the presence of displaced benthic foraminifera from shallow water do support trigger ing mechanisms other than mud volcanism.

Conversely, several lines of evidence suggest that resedimented units in CALA 21 might be triggered seismically. They include: a) multi source and variable provenance of turbidite sediments as deduced from foraminiferal associations and sediment composition (mainly TOC); b) the occurrence of similar seismoturbidites in other regions of the CA (Supplementary Material 1) and in the Hellenic trench 
(Anastasakis and Piper, 1991); c) a clear correlation with seismically triggered processes leading to the deposition of turbidite beds in the Ionian Sea during the last millennia (Polonia et al., 2013a); and d) a frequency of occurrence similar to that of large magnitude $\left(\mathrm{M}_{\mathrm{w}}>6.0\right)$ historical earthquakes in the study area (CPTI Working Group, 2004).

The presence of resedimented sapropelic sediments within the turbidites (high TOC in the turbidites relative to the background) provides information on sediment sources, because it implies that some high TOC sedimentary material was entrained from continental slopes during sediment remobilization. This is confirmed by foraminiferal associations, which include species from different bathymetric ranges, suggesting random failures or multiple sediment sources from different physiographic domains. Isotopic composition of organic matter suggests a marine provenance of organic carbon, while, wood fragments and land derived plants present within the resedimented beds point towards a continental input. In summary, we could consider two possible alternative scenarios: 1) seismicity causing slumps over a wide area, or 2) turbidity currents initiated on the steeper uppermost slope that could have possibly eroded surficial material also from the lower slope.

A sequence of turbidite events similar to that observed within $\mathrm{S} 1$ in CALA 21 was recognized in the western Hellenic trench, where seismic triggering was proposed, based on the apparently synchronicity of turbidites from different drainage systems (Anastasakis and Piper, 1991) as in the Cascadia margin (Adams, 1990).

We should furthermore consider that the northern Ionian Sea is one of the most seismically active regions in the Mediterranean. More than $90 \%$ of sediment volume deposited in the abyssal plain during the Holocene is due to turbidity currents triggered by earthquakes and/or tsunami waves (Polonia et al., 2013a, 2013b). Its peculiar location in the middle of two subduction systems (Calabrian and Hellenic Arcs), makes this region an ideal sink for turbidity flows caused by shaking of near and far field sources of both systems. It has been observed that strong earthquakes generated in the relatively distant Hellenic Arc could produce much larger catastrophic effects in the CA than most of those originating closer (Polonia et al., 2013b). A long list of earthquakes is known, both for Calabria and western Greece from his torical catalogues (Guidoboni et al., 1994; CPTI Working Group, 2004) and modern seismological observations (Castello et al., 2006; Shaw and Jackson, 2010).

The discovery and dating of three recent seismoturbidites in the Messina Straits region have pointed out that major earthquakes in the CA (i.e. 1908, 1693 and 1169) triggered turbidity currents and massflows from the continental shelf down to the abyssal plain (Polonia et al., 2013a). In the Ionian Sea, where historical earthquakes have magnitude $\mathrm{M}_{\mathrm{w}}<7.5$, decimetric thick seismoturbidites occur, due to the physiography and tectonic setting of the margin, characterized by uplifting coastal mountain belts (Southern Apennines) discharging into the basins large quantities of sediments that increase the potential for mass failures.

In analogy with the mechanisms proposed for more recent seismoturbidites from the Calabria margin (Polonia et al., 2013a), we suggest that the most likely driving mechanism for the observed turbidite emplacement within sapropel S1 is ground acceleration due to seismic events and/or impact on the seafloor of tsunami waves.

Although more than 25 earthquakes with $M_{w}>6$ between the Messina Strait and Calabria are reported in the catalogue since 91 B.C., only 7 of them were located along the Ionian coast (CPTI Working Group, 2004) during the last 2 millennia. This record is in good agreement with our findings, which include 9 major events and 5 thinner (few mm thick) turbidite beds for a total of 13 mass flow deposits during the $4200 \mathrm{yr}$ of sapropel deposition. On the other hand, analysis of CALA 21 core, suggests that during the last $2000 \mathrm{yr}$ (after deposition of tephra layer Z1) three main turbidite beds were deposited, that may correspond to seismic events described on land in this area (Galli and Bosi, 2003; Galli et al., 2006).
Based on their mineral content, we can exclude a Greek provenance for most of the S1 turbidites. In fact, it suggests a source from low grade metamorphic basement rocks typical of Calabria.

\subsection{Sapropel chronologies and recurrence time of turbidites}

A simple repeat time estimate for the seismoturbidites within $\mathrm{S} 1$, in the order of $500 \mathrm{yr}$, was deduced considering the chronology of sapropel S1 according to our radiometric results (i.e. $4200 \mathrm{yr}$ ) and the number of turbidite TS beds (9). However, the age modeling refined such estimate (Table 5), and suggested that repeat time is not constant, but varies between 100 and $700 \mathrm{yr}$.

Analysis of turbidite beds above sapropel S1, detected 12 turbidites deposited between the sapropel S1 top ( $6.0 \mathrm{ka}$ cal. BP) and the seafloor, with an average recurrence time of about $500 \mathrm{yr}$. These findings suggest that during and after sapropel S1 deposition, seismicity regime did not substantially change (within errors intimately associated to such analysis), even though clusters of earthquakes may have occurred in specific time periods as shown by our data, by onshore paleoseismology (Galli and Bosi, 2003; Galli et al., 2006) and historical catalogues (CPTI Working Group, 2004).

The inferred average recurrence time is a maximum average, because not all the earthquakes are likely to leave their signature in the sub seafloor, especially on top of a topographic high, as is the case of CALA 21 station. Anastasakis and Piper (1991), in fact, studied cores collected in different oceanographic settings, including a structural high, and found that not all turbidity currents entering the basin were thick enough to deposit material on the highs.

Finally, age modeling suggests that turbidites TS 4 and TS 5 fall in the time range suggested for the emplacement of the well known "sapropel interruption" observed in the whole Eastern Mediterranean basin (de Rijk et al., 1999; Mercone et al., 2000). The coincidence of our earthquake related turbidites with a climate related feature may be mechanistic or fortuitous. In any case, for this study and with the data presently available, any discussion on this interesting topic would be premature.

\section{Conclusions}

Nine prominent turbidite beds observed within sapropel S1, in a sediment core collected from a topographic high in the northern Ionian Sea, interrupt anoxic conditions and represent more than $40 \%$ of total sediment thickness during sapropel S1 deposition (10.2 $6.0 \mathrm{ka} \mathrm{cal} \mathrm{BP).}$ Mass flow units were studied through an integrated approach involving sedimentology, micropaleontology, mineralogy and geochemistry. By combining stratigraphic reconstructions, turbidite structure, age modeling, and previous studies on the interplay between seismic shaking and sedimentation, we conclude that the emplacement of the turbidites may be correlated to the occurrence of major earthquakes. Main indica tors include: a) multi source and variable provenance of turbidite sediments, as deduced from foraminifera associations and sediment composition; b) occurrence of similar seismoturbidites in other regions of the CA and in the Hellenic trench; c) correlation with seismically triggered processes leading to the deposition of turbidite beds during the last millennia in the Ionian Sea; and d) average recurrence frequen cies similar to that of large magnitude $\left(M_{w}>6.0\right)$ historical earthquakes in the area.

Average recurrence of seismoturbidites within sapropel S1, deduced considering chronology and number of turbidites, is about $500 \mathrm{yr}$, and appears to be constant also before and after its deposition. This is in good agreement with the average frequency of major earthquakes in Calabria during historical time. However, age modeling performed on the entire sequence suggests that recurrence time is not constant, but rather it varies between 100 and $700 \mathrm{yr}$.

These findings enable us to extend back in time the paleoseismic catalogue of major seismic events in the Calabrian Arc during a time 
span that includes a number of seismic cycles, and will help improving seismic hazard assessment for Southern Italy.

Supplementary data to this article can be found online at http://dx. doi.org/10.1016/j.margeo.2015.01.001.

\section{Acknowledgments}

The CALAMARE scientific party, Captain Lubrano, Urania shipboard and SOPROMAR parties are greatly acknowledged for the contribution in core collection during the Urania cruise. We thank G. Bortoluzzi, A. Gallerani, L. Marozzi, R. G. Lucchi, F. Savelli, L. Langone and F. Riminucci for help in data acquisition and core analysis. We thank T. Goslar of the Poznań Radiocarbon Laboratory Foundation of the Adam Mickiewicz University (Poland) for his assistance in radiometric dating. A special thank to A. Correggiari and E. Bonatti for fruitful discussions. MNÇ ac knowledges the international collaboration project support by TUBITAK (project no. 111Y187). We are greatly indebited with the Editor Gert J. De Lange as well as C. Goldfinger and an anonymous reviewer for very constructive comments. This work was supported by the PRIN project (Prot 20103KTT94_002): "Active and recent geodynamics of Calabrian Arc and accretionary complex in the Ionian Sea" coordinated by Prof. C. Monaco (ISMAR paper no. 1853).

\section{References}

Adams, J., 1990. Paleoseismicity of the Cascadia subduction zone: evidence from turbidites off the Oregon-Washington margin. Tectonics 9, 569-583. http://dx.doi.org/ 10.1029/TC009i004p00569.

Anastasakis, G.P., Piper, D.J.W., 1991. The character of seismoturbidites in the S-1 sapropel, Zakinthos and Strofadhes basins, Greece. Sedimentology 38, 717-733.

Antonioli, F., Ferranti, L., Lambeck, K., Kershaw, S., Verrubbi, V., Dai Pra, G., 2006. Late Pleistocene to Holocene record of changing uplift rates in southern Calabria and northeastern Sicily (southern Italy, Central Mediterranean Sea). Tectonophysics 422, 23-40.

Barnes, P.M., Bostock, H.C., Neil, H.L., Strachan, L.J., Gosling, M., 2013. A 2300-year paleoearthquake record of the Southern Alpine Fault and Fiordland Subduction Zone, New Zealand, based on stacked turbidites. Bulletin of the Seismological Society of America 103 (4), 2424-2446. http://dx.doi.org/10.1785/0120120314.

Boschi, E., Guidoboni, E., Ferrari, G., Mariotti, D., Valensise, G., Gasperini, P., 2000. Catalogue of strong Italian earthquakes from 461 B.C. to 1997. Annali di Geofisica 43, 609-868.

Bottari, A., Capuano, P., De Natale, G., Gasperini, P., Neri, G., Pingue, F., Scarpa, R., 1989 Source parameters of earthquakes in the Strait of Messina, Italy, during this century. Tectonophysics 166, 221-234.

Bronk Ramsey, C., 2008. Deposition models for chronological records. Quaternary Science Reviews 27, 42-60.

Bronk Ramsey, C., Dee, M., Lee, S., Nakagawa, T., Staff, R., 2010. Developments in the calibration and modelling of radiocarbon dates. Radiocarbon 52 (3), 953-961.

Cagatay, M.N., Erel, L., Bellucci, L.G., Polonia, A., Gasperini, L., Eris, K., Sancar, Ü., Biltekin, D Uçarkus, G., Ülgen, U.B., Damci, E., 2012. Sedimentary earthquake records in the Izmit Gulf, Sea of Marmara, Turkey. Sedimentary Geology 282, 347-359. http://dx.doi.org/ 10.1016/j.sedgeo.2012.10.001.

Cernobori, L., Hirn, A., McBride, J.H., Nicolich, R., Petronio, L., Romanelli, M., STREAMERS/ PROFILES Working Groups, 1996. Crustal image of the Ionian basin and its Calabrian margins. Tectonophysics 264, 175-189.

Castello, B., Selvaggi, G., Chiarabba, C., Amato, A., 2006. CSI Catalogo della sismicità italiana 1981-2002, versione 1.1. INGV-CNT, Roma.

Crudeli, D., Young, J.R., Erba, E., Geisen, M., Ziveri, P., de Lange, G.J., Slomp, C.P., 2006. Fossil record of holococcoliths and selected hetero-holococcolith associations from the Mediterranean (Holocene-late Pleistocene): Evaluation of carbonate diagenesis and palaeoecological-palaeocenographic implications. Palaeogeography, Palaeoclimatology, Palaeoecology 237, 191-224.

CPTI Working Group, 2004. Catalogo Parametrico dei Terremoti Italiani, versione 2004 (CPTI04). INGV, Bologna http://dx.doi.org/10.6092/INGV.IT-CPTI04 (http://emidius. mi.ingv.it/CPTI04/, Available at november 2013).

D'Agostino, N., Avallone, A., Cheloni, D., D'Anastasio, E., Mantenuto, S., Selvaggi, G., 2008 Active tectonics of the Adriatic region from GPS and earthquake slip vectors. Journa of Geophysical Research 113, B12413. http://dx.doi.org/10.11029/12008JB005860.

De Lange, G.J., Catalano, G., Klinkhammer, G.P., Luther III, G.W., 1990. The interface between oxic seawater and the anoxic Bannock brine; its sharpness and the consequences for the redox related cycling of $\mathrm{Mn}$ and Ba. Marine Chemistry 31 (1-3), 205-217. http://dx.doi.org/10.1016/0304- 4203(90)90039-F.

De Lange, G.J., Thomson, J., Reitz, A., Slomp, C.P., Principato, M.S., Erba, E., Corselli, C., 2008. Synchronous basin-wide formation and redox-controlled preservation of a Mediterranean sapropel. Nature Geoscience 1, 606-610.

De Rijk, S., Hayes, A., Rohling, E.J., 1999. Eastern Mediterranean sapropel S1 interruption: an expression of the onset of climatic deterioration around $7 \mathrm{ka}$ BP. Marine Geology 153, 337-343. http://dx.doi.org/10.1016/S0025-3227(98)00075-9.
Ferranti, L., Monaco, C., Antonioli, F., Maschio, L., Kershaw, S., Verrubbi, V., 2007. The contribution of regional uplift and coseismic slip to the vertical crustal motion in the Messina Straits, southern Italy: evidence from raised Late Holocene shorelines. Journal of Geophysical Research 112, B06401. http://dx.doi.org/10.1029/2006JB004473.

Friedman, G.M., Sanders, J.E., 1978. Principles of Sedimentology. John Wiley \& Sons, New York (792 pp.).

Galli, P., Bosi, V., 2003. Catastrophic 1638 earthquakes in Calabria (southern Italy): new insights from paleoseismological investigation. Journal of Geophysical Research 108, B1. http://dx.doi.org/10.1029/2001JB001713.

Galli, P., Ruga, A., Scionti, V., Spadea, R., 2006. Archaeoseismic evidence for a Late Roman earthquake in the Crotone area (Ionian Calabria, Southern Italy): seismotectonic implications. Journal of Seismology 10, 443-458. http://dx.doi.org/10.1007/s10950006-9030-2.

Goldfinger, C., Nelson, C.H., Johnson, J.E., 2003. Deep-water turbidites as Holocene earthquake proxies: the Cascadia Subduction Zone and northern San Andreas Fault systems. Annals of Geophysics 46, 1169-1194.

Goldfinger, C., Morey, A., Nelson, C.H., Gutierrez-Pastor, J., Johnson, J.E., Karabanov, E., Chaytor, J., Eriksson, A., The Shipboard Scientific Party, 2007. Rupture lengths and temporal history of significant earthquakes on the offshore and North Coast segments of the Northern San Andreas Fault based on turbidite stratigraphy. Earth and Planetary Science Letters 254, 9-27.

Goldfinger, C. Grijalva, K. Burgmann, K. Morey, A, Johnson, J.E., Nelson, C.H., GutiérrezPastor, J., Karabanov, E., Patton, J., Gracia, E., 2008. Late Holocene rupture of the northern San Andreas Fault and possible stress linkage to the Cascadia Subduction Zone. Bulletin of the Seismological Society of America 98, 861-899.

Goldfinger, C., 2011. Submarine Paleoseismology Based on Turbidite Records. Annual Review of Marine Science 3, 35-66. http://dx.doi.org/10.1146/annurev-marine-120709-142852.

Goldfinger, C., Nelson, C.H., Morey, A., Johnson, J.E., Gutierrez-Pastor, J., Eriksson, A.T., Karabanov, E., Patton, J., Gracia, E., Enkin, R., Dallimore, A., Dunhill, G., Vallier, T., 2012. Turbidite event history-methods and implications for Holocene paleoseismicity of the Cascadia subduction zone. U.S. Geological Survey Professional Paper 1661-F (170 pp., http://pubs.usgs.gov/pp/pp1661f, available at November 2013).

Govers, R., Wortel, M.J.R., 2005. Lithosphere tearing at STEP faults: response to edges of subduction zones. Earth and Planetary Science Letters 236, 505-523.

Gracia, E., Vizcaino, A., Escutia, C., Asioli, A., Rodés, A., Pallàs, R., Garcia-Orellana, J., Lebreiro, S., Goldfinger, C., 2010. Holocene earthquake record offshore Portugal (SW Iberia): testing turbidite paleoseismology in a slow-convergence margin. Quaternary Science Reviews 29, 1156-1172. http://dx.doi.org/10.1016/j.quascirev.2010.01.010.

Guidoboni, E., Comastri, A., Traina, G., 1994. Catalogue of Ancient Earthquakes in the Mediterranean Area up to 10th Century. Istituto Nazionale di Geofisica e Vulcanologia-Storia Geofisica Ambiente, Bologna (504 pp.).

Higgins, M.B., Robinson, R.S., Carter, S.J., Pearson, A., 2010. Evidence from chlorin nitrogen isotopes for alternating nutrient regimes in the Eastern Mediterranean Sea. Earth and Planetary Science Letters 290, 102-107.

Jacques, E., Monaco, C., Tapponnier, P., Tortorici, L., Winter, T., 2001. Faulting and earthquake triggering during the 1783 Calabria seismic sequence. Geophysical Journal International 147, 1-25.

Jenny, S., Goes, S., Giardini, D., Kahle, H.-G., 2006. Seismic potential of Southern Italy. Tectonophysics 415, 81-101.

Kastens, K.A., 1984. Earthquakes as a triggering mechanism for debris flows and turbidites on the Calabrian Ridge. Marine Geology 55, 13-33.

Kidd, R.B., Cita, M.B., Ryan, W.B.F., 1978. Stratigraphy of eastern Mediterranean sapropel sequences recovered during DSDP Leg $42 \mathrm{~A}$ and their paleoenvironmental significance. Initial Reports of the Deep Sea Drilling Project 42A, 421-443.

Lamb, A.L., Wilson, G.P., Leng, M.J., 2006. A review of coastal palaeoclimate and relative sea-level reconstructions using $\delta^{13} \mathrm{C}$ and $\mathrm{C} / \mathrm{N}$ ratios in organic material. EarthScience Reviews 75 (1-4), 29-57.

Lambeck, K., Antonioli, F., Purcell, A., Silenzi, S., 2004. Sea-level change along the Italian coast for the past 10,000 yr. Quaternary Science Reviews 23, 1567-1598.

Langereis, C.G., Dekkers, M.J., de Lange, G.J., Paterne, M., van Santvoort, P.J.M., 1997. Magnetostratigraphy and astronomical calibration of the last $1.1 \mathrm{Myr}$ from an eastern Mediterranean piston core and dating of short events in the Brunhes. Geophysical Journal International 129, 75-94.

McHugh, C.M.G., Seeber, L., Cormier, M.-H., Dutton, J., Cagatay, M.N., Polonia, A., Ryan, W.B.F., Görür, N., 2006. Submarine earthquake geology along the North Anatolian Fault in the Marmara Sea, Turkey: a model for transform basin sedimentation. Earth and Planetary Science Letters 248, 661-684. http://dx.doi.org/10.1016/j.epsl. 2006.05.038

McHugh, C.M., Seeber, L., Braudy, N., Cormier, M.-H., Davis, M.B., Diebold, J.B., Dieudonne, N., Douilly, R., Gulick, S.P.S., Hornbach, M.J., Johnson III, H.E., Ryan, K.M., Sorlien, C.C., Steckler, M.S., Symithe, S.J., Templeton, J., 2011. Offshore sedimentary effects of the 12 January 2010 Haiti earthquake. Geology 39, 723-726.

Mercone, D., Thomson, J., Croudace, I.W., Siani, G., Paterne, M., Troelstra, S., 2000. Duration of S1, the most recent sapropel in the eastern Mediterranean Sea, as indicated by AMS radiocarbon and geochemical evidence. Paleoceanography 15, 336-347. http://dx.doi.org/10.1029/1999PA000397.

Mercone, D., Thomson, J., Abu-Zied, R.H., Croudace, I.W., Rohling, E.J., 2001. High resolution geochemical and micropaleontological profiling of the most recent eastern Mediterranean sapropel. Marine Geology 177, 25-44.

Morelli, D., Cuppari, A., Colizza, E., Fanucci, F., 2011. Geomorphic setting and geohazardrelated features along the Ionian Calabrian margin between Capo Spartivento and Capo Rizzuto (Italy). Marine Geophysical Research 32, 139-149. http://dx.doi.org/ 10.1007/s11001-011-9130-4.

Mulder, T., Mignon, S., Savoye, B., Faugeres, J.-C., 2001. Inversely graded turbidite sequences in the deep Mediterranean. A record of deposits from flood-generated turbidity currents? Geo-Marine Letters 21, 86-93. 
Mulder, T., Syvitski, J.P.M., Migeon, S., Faugères, J.C., Savoye, B., 2003. Marine hyperpycnal flows: initiation, behavior and related deposits. A review. Marine and Petroleum Geology 20, 861-882. http://dx.doi.org/10.1016/j.marpetgeo.2003.01.003.

Murat, A., Got, H., Cauwet, G., Buscail, R., 1990. Facteurs de la variabilité du taux de carbone organique du sapropèl holocène de la Méditerranée orientale. Rapp. P. Réun. Commun int. Exp./or scient. Mer médit. 32 p. 45.

Nelson, C.H., Escutia, C., Damuth, J.E., Twichell, D.C., 2009a. Interplay of mass-transport and turbidite-system deposits in different active tectonic and passive continental margin settings: external and local controlling factors. Mass Transport Deposits in Deep Water Settings. 95. SEPM Special Publication, pp. 1-28.

Nelson, C.H., Escutia, C., Goldfinger, C., Karabanov, E., Gutierrez-Pastor, J., De Batist, M., 2009b. External controls on modern clastic turbidite systems: three case studies. In: Kneller, B., Martinsen, O.J., McCaffrey, W. (Eds.), Society for Sedimentary Geology Special Publication vol. 92. Society for Sedimentary Geology, London, pp. 57-76.

Neri, G., Orecchio, B., Totaro, C., Falcone, G., Presti, D., 2009. Subduction beneath Southern Italy close the ending: results from seismic tomography. Seismological Research Letters 80 (1), 63-70.

Neri, G., Marotta, A.M., Orecchio, B., Presti, D., Totaro, C., Barzaghi, R., Borghi, A., 2012. How lithospheric subduction changes along the Calabrian Arc in southern Italy: geophysical evidences. International Journal of Earth Science (Geol Rundsch) 101 (7), 1949-1969. http://dx.doi.org/10.1007/s00531-012-0762-7.

Ogrinc, N., Fontolan, G., Faganeli, J., Covelli, S., 2005. Carbon and nitrogen isotopic compositions of organic matter in coastal marine sediments (the Gulf of Trieste, N Adriatic Sea): indicators of sources and preservation. Marine Chemistry 95, 163-181.

Panieri, G., Polonia, A., Lucchi, R.G., Zironi, S., Capotondi, L., Negri, A., Torelli, L., 2013. Mud volcanoes along the inner deformation front of the Calabrian Arc accretionary wedge (Ionian Sea). Marine Geology 336, 84-98.

Patton, J.R., Goldfinger, C., Morey, A., Erhardt, M., Black, B., Garrett, A.M., Djadjadihardja, Y.S., Hanifa, U., 2010. Temporal clustering and recurrence of Holocene paleoearthquakes in the region of the 2004 Sumatra-Andaman earthquake. Seismological Society of America Annual Meeting vol. 41, p. 408 (Portland, OR).

Piatanesi, A., Tinti, S., 1998. A revision of the 1693 eastern Sicily earthquake and tsunami. Journal of Geophysical Research 103, 2749-2758.

Polonia, A., Torelli, L., Mussoni, P., Gasperini, L., Artoni, A., Klaeschen, D., 2011. The Calabrian Arc subduction complex in the Ionian Sea: regional architecture, active deformation and seismic hazard. Tectonics 30, TC5018. http://dx.doi.org/10.1029/ 2010 TC002821.

Polonia, A., Torelli, L., Gasperini, L., Mussoni, P., 2012. Active faults and historical earthquakes in the Ionian Sea. Natural Hazards and Earth System Sciences 12, 2311-2328. http://dx.doi.org/10.5194/nhess-12-2311-2012.

Polonia, A., Panieri, G., Gasperini, L., Gasparotto, G., Bellucci, L.G., Torelli, L., 2013a. Turbidite paleoseismology in the Calabrian Arc subduction complex (Ionian Sea). Geochemistry, Geophysics, Geosystems 14, 112-140. http://dx.doi.org/10.1029/ 2012 GC004402.

Polonia, A., Bonatti, E., Camerlenghi, A., Lucchi, R.G., Panieri, G., Gasperini, L., 2013b. Mediterranean megaturbidite triggered by the AD 365 Crete earthquake and tsunami. Scientific Reports 3, 1285. http://dx.doi.org/10.1038/srep01285 (ISSN (online): 20452322).

Pouderoux, H., Lamarche, G., Proust, J.-N., 2012. Building an 18 000-year-long paleoearthquake record from detailed deep-sea turbidite characterisation in Poverty Bay, New Zealand. Natural Hazards and Earth System Sciences 12, 2077-2101. http://dx. doi.org/10.5194/nhess-12-2077-2012.
Rohling, E.J., Hilgen, F.J., 1991. The eastern Mediterranean climate at times of saprope formation: a review. Geologie en Mijnbouw 70 (253-264), 1991.

Rohling, E.J., Cane, T.R., Cooke, S., Sprovieri, M., Bouloubassi, I., Emeis, K.C., Schiebel, R., Kroon, D., Jorissen, F.J., Lorre, A., Kempet, A.E.S., 2002. African monsoon variability during the previous interglacial maximum. Earth and Planetary Science Letters 202, 61-75.

Rossignol-Strick, M., Nesteroff, W., Olive, P., Vergnaud-Grazzini, C., 1982. After the deluge: Mediterranean stagnation and sapropel formation. Nature 295, 105-110.

Rossignol-Strick, M., 1985. Mediterranean Quaternary sapropels, an immediate response of the African monsoon to variation of insolation. Palaeogeography, Palaeoclimatology, Palaeoecology 49, 237-263.

Rothwell, R.G., Thomson, J., Kähler, G., 1998. Low-sea-level emplacement of a very large Late Pleistocene 'megaturbidite' in the western Mediterranean Sea. Nature 392, 377-380. http://dx.doi.org/10.1038/32871.

Rothwell, R.G., Reeder, M.S, Anastasakis, G, Stow, D.A.V., Thomson, J, Kahler, G., 2000. Low sea-level emplacement of megaturbidites in western and eastern Mediterranean Sea. Sedimentary Geology $135,75-88$

Shanmugam, G., 2013. New perspectives on deep-water sandstones: implications. Petroleum Exploration and Development 40 (3), 316-324

Shaw, B., Jackson, J., 2010. Earthquake mechanisms and active tectonics of the Hellenic subduction zone. Geophysical Journal International 181, 966-984. http://dx.doi.org/ 10.1111/j.1365-246X.2010.04551.

Stanley, D.J., 1981. Unifites: structureless muds of gravity-flow origin in Mediterranean basins. Geo-Marine Letters 1 (2), 77-83.

Strasser, M., Monecke, K., Schnellmann, M., Anselmetti, F.S., 2013. Lake sediments as natural seismographs: a compiled record of Late Quaternary earthquakes in Centra Switzerland and its implication for Alpine deformation. Sedimentology 60 319-341. http://dx.doi.org/10.1111/sed.12003.

Tinti, S., Maramai, A., Graziani, L., 2004. The new catalogue of the Italian tsunamis. Natural Hazards 33, 439-465.

Thomson, J., Mercone, D., De Lange, G.J., Van Santvoort, P.J.M., 1999. Review of recent advances in the interpretation of eastern Mediterranean sapropel S1 from geochemical evidence. Marine Geology 153, 77-89.

Urgeles, R., Masson, D.G., Canals, M., Watts, A.B., Le Bas, T., 1999. Recurrent, large-scale landsliding on the West flank of La Palma Canary Islands. Journal of Geophysical Research 104, 25,331-25,348.

Van Daele, M., Cnudde, V., Duyck, P., Pino, M., Urrutia, R., De Batist, M., 2013. Multidirectional, synchronously-triggered seismo-turbidites and debrites revealed by X-ray computed tomography (CT). Sedimentology http://dx.doi.org/10.1111/sed.12070.

Weaver, P.P.:E., Kuijpers, A., 1983. Climatic control of turbidite deposition on the Madeira Abyssal plain. Nature 306, 360-363. http://dx.doi.org/10.1038/306360a0.

Wulf, S., Kraml, M., Keller, J., 2008. Towards a detailed distal tephrostratigraphy in the Central Mediterranean: the last 20,000 yr record of Lago Grande di Monticchio. Journal of Volcanology and Geothermal Research 177, 118-132.

Zanchetta, G., Sulpizio, R., Roberts, N., Cioni, R., Eastwood, W.J., Siani, G., Caron, B., Paterne, M., Santacroce, R., 2011. Tephrostratigraphy, chronology and climatic events of the Mediterranean basin during the Holocene: an overview. The Holocene 21 (1) 33-52. http://dx.doi.org/10.1177/0959683610377531. 